\title{
N-Glycosylation modification of proteins is an early marker of the enterocytic differentiation process of HT-29 cells
}

\author{
E Ogier-Denis ${ }^{1 *}, \mathrm{C}$ Bauvy ${ }^{1}, \mathrm{M}$ Aubery ${ }^{1}, \mathrm{P}$ Codogno ${ }^{1}$, \\ C Sapin 2, D Darmoul 2, A Zweibaum 2, G Trugnan 2 \\ 1 UFR Biomédicalo des Saint-Pères, (INSERM U180), \\ Unité de Recherches sur la Biologie et Pathologie Moléculaires des Glycoproteines \\ 45, rue des Saints-Pères, 75006, Paris; \\ 2 INSERM U178, Unité de Recherches sur la Différenciation et la Neuroendocrinologie \\ de Cellules Digestives, Bâtiment INSERM, 16, avenue Paul-Vaillant Couturier, \\ 94807 Villejuif Cedex, France
}

(15th meeting of the INRA Development group, Paris, 24-26 May 1989)

Summary - The human colon cancer cell line HT-29 remains totally undifferentiated when glucose is present in the culture medium (HT-29 Glc ${ }^{+}$), while the same cells may undergo typical enterocytic differentiation after reaching confluence when grown in glucose-deprived medium (HT-29 Glc-). $\mathrm{Re}^{-}$ cently, we demonstrated a deficiency in the overall $\mathrm{N}$-glycan processing in confluent undifferentiated cells, whereas differentiated cells follow a classical pattern of $\mathrm{N}$-glycosylation. The main changes in $\mathrm{N}$-glycosylation observed in confluent undifferentiated cells may be summarised as follows: 1) the conversion of high mannose into complex glycopeptides is greatly decreased; 2) this decreased conversion could be a consequence of an accumulation of $\mathrm{Man}_{9-8}-\mathrm{GlcNAC}_{2}-\mathrm{Asn}_{\text {high mannose spe- }}$ cies. Whether these changes in $\mathrm{N}$-glycan processing appear progressively during cell culture or are already present from the beginning of the culture was investigated in this study by comparing the actual status of $\mathrm{N}$-glycan processing in exponentially growing HT-29 Glc and $\mathrm{HT}^{-29} \mathrm{Glc}^{+}$cells. Under these conditions, HT-29 Glc cells do not exhibit any characteristics of differentiation. The conversion of high mannose into complex glycoproteins is severely reduced in $\mathrm{HT}-29 \mathrm{Glc}^{+}$cells, regardless of the growth phase studied. In contrast, HT-29 Glc- cells display a normal pattern of N-glycan processing in both growth phases. We therefore conclude that $\mathrm{N}$-glycan processing may be used as an early biochemical marker of the enterocytic differentiation process of HT-29 cells.

N-glycan trinning / high mannose type chain / enterocytic differentiation / colon cancer / early blochemical marker

Résumé - La N-glycosylation des protéines est un marqueur précoce de la différenciation entérocytaire des cellules HT-29. Les cellules HT-29, dérivées d'un adénocarcinome humain d'origine colique et cultivées en présence de glucose ( $\mathrm{HT}-29 \mathrm{Glc} \mathrm{c}^{+}$) demeurent indifférenciées alors que les mêmes cellules, cultivées en absence de glucose (HT-29 Glc ${ }^{-}$) experiment, après confluence cellulaire, une différenciation entérocytaire typique. Cette étude réalisée après confluence a permis

\footnotetext{
* Correspondance and reprints
} 
de mettre en évidence différentes altérations dans le métabolisme des $\mathrm{N}$-glycannes des cellules $H T$ $29 \mathrm{Gl}^{+}$, qui ne sont pas observées dans les cellules HT-29 Glc-: 1) la maturation des chaînes oligomannosidiques en chaînes de type complexe est fortement réduite dans ces cellules; 2) une forte accumulation de chaînes oligomannosidiques comportant 9 à 8 résidus de mannose peut être détectée. De plus, le modèle HT-29 permet d'étudier les événements biochimiques précoces qui se mettent en place avant l'acquisition de la différenciation des cellules HT-29 Glc-. En effet, en phase exponentielle de croissance, les cellules.HT $2 A$ Glc ${ }^{-}$et HT $2 A$ Glc sont phénotypiquement indifférenciées, malgré leur devenir différent après confluence.

métabolisme des N-glycannes / chaîne oligomannosidique / différenciation entérocytaire / cancer collque / marqueur biochimique précoce

\section{INTRODUCTION}

The HT-29 cell line (Fogh and Trempe, 1975) derived from a human colon adenocarcinoma, is an excellent model for the study of the dynamics and positioning of the elements involved in cell differentiation. In fact, the same cells can undergo typical enterocytic differentiation when they are grown without glucose (HT-29 Glc-), or remain totally undifferentiated when cultured in the presence of glucose (HT-29 Glc ${ }^{+}$) (Zweibaum et al, 1985). It is only after confluence has been reached that the morphological and enzymatic characteristics of differentiation appear in HT-29 Glc- cells. Recently, we demonstrated that the entire protein glycosylation process is markedly perturbed in confluent undifferenciated cells, whereas the differentiated cells undergo classical glycosylation at the same growth stage (OgierDenis et al, 1988). It remains important to determine whether the modifications of coand post-translational mechanisms precede the expression of the morphological and enzymatic characteristics of HT-29 Glc- cell differentiation or not. The HT-29 system, for which the stage of diffentiation can be predicted and modulated simply by modifying the culture medium, enables an approach to be made to these types of questions. Thus, we have studied $\mathrm{N}$ - glycosylation of HT-29 cells during the exponential growth phase.

\section{MATERIALS AND METHODS}

\section{Cells and cell culture}

HT-29 cells were cultured in the presence of 2.5 $\mathrm{mmol} / \mathrm{inosine}$ in the absence of glucose (permissive condition of differentiation) or with 25 $\mathrm{mmol} / \mathrm{glucose}$ (non-permissive condition of differentiation). Cells were used after reaching confluence (d 20) when HT-29 Glc- cells underwent typical enterocytic differentiation, and during the exponential growth phase (d 5) when the differentiation markers were not yet expressed in HT-29 Glc- cells.

\section{Metabolic labelling and chromatography}

Cells were radiolabelled with $\mathrm{D}-[2-3 \mathrm{H}]-$ mannose $(20 \mathrm{Ci} / \mathrm{mmole}$, The Amersham Radiochemical Centre, UK) for $10 \min (400 \mu \mathrm{Ci} / \mathrm{ml})$ and $24 \mathrm{~h}(40 \mu \mathrm{Ci} / \mathrm{ml})$. During pulse-chase experiments, $5 \mathrm{mmol} / \mathrm{l}$ of non-radioactive mannose and $2 \mathrm{mmol} / \mathrm{h}$ of non-radioactive fucose were added. After metabolic labelling, the cellular glycoproteins were extracted successively by a mixture of chloroform-methanol $(2: 1, v / v)$ and a mixture of chloroform-methanol-water (10:10:3, $v / v / v)$, and then exhaustively digested with pronase (2 mg/ml; CB grade, Calbiochem, France) 
at $60^{\circ} \mathrm{C}$ for $24 \mathrm{~h}$ under a toluene atmosphere (Ogier-Denis et al, 1988). The glycopeptides obtained were then chromatographed on a Bio-Gel P6 column (1 x $130 \mathrm{~cm}, 200-400$ mesh; Bio-Rad, USA), according to the technique of Codogno et al (1985). Each fraction was treated with $2.5 \mathrm{mU}$ of Streptomyces griseus endo- $\beta-\mathrm{N}$ acetylglucosaminidase $H$ (endo $H$ ) (Miles, France) in $100 \mu$ l of citrate buffer, $\mathrm{pH} \mathrm{5.0,}$ for $18 \mathrm{~h}$ at $37^{\circ} \mathrm{C}$ under a toluene atmosphere (Tarentino and Maley, 1974). The samples were heated at $100{ }^{\circ} \mathrm{C}$ for $3 \mathrm{~min}$ and chromatographed on a Bio-Gel P6 column.

\section{High performance liquid chromatography (HPLC)}

The oligosaccharides released by endo $\mathrm{H}$ were fractionated by HPLC (Varian model 5000 equipped with a $5 \mu$ aminospherisorb column). The samples were co-eluted with oligosaccharide standards radiolabelled with $\left[{ }^{14} \mathrm{C}\right]$-mannose. The dolichol-linked oligosaccharide chains, extracted in the chloroform-methanol-water $(10: 10: 3, v / v / v)$ phase, were analysed as reported by Roméro and Herscovics (1986). Briefly, the oligosaccharides were separated from dolichol by controlled acid hydrolysis $(0.01 \mathrm{~mol} / \mathrm{l}$ $\mathrm{HCl}$ for $45 \mathrm{~min}$ at $90^{\circ} \mathrm{C}$ ). After neutralization and desalting, the oligosaccharides were fractionated by HPLC as described above. Regardless of the cell population, the oligosaccharides $\mathrm{Glc}_{3}-\mathrm{Man}_{9}-\mathrm{GlcNAc}_{1}$ were detected both during the exponential growth phase and after reaching cellular confluence.

\section{RESULTS}

\section{Undifferentiated cells accumulated a high proportion of high mannose chains during exponential and stationary growth phases}

The glycopeptides, obtained from metabolically labelled (D-[2-3 $\mathrm{H}]$-mannose for 24 h) HT-29 cells following exhaustive Pronase digestion of the glycoproteins, were chromatographed on a Bio-Gel P6 column (table 1). Four fractions were identified in the 2 cell populations. Only fraction IV was sensitive to the enzymatic action of endo $\mathrm{H}$ and was strongly retained on a column of immobilized concanavalin $A$. The distribution of the glycopeptides isolated from HT29 cells during their exponential growth phase was comparable to that found for confluent cells (table I). Regardless of the growth phase considered, HT-29 Glc cells expressed a very high proportion of high mannose chains (fraction IV).

\section{Alteration of the processing of high mannose chains is an early event in undifferentiated cells}

In order to understand more fully the accumulation of high mannose species in HT$29 \mathrm{Glc}^{+}$cells, $\mathrm{N}$-glycan biosynthesis and processing in HT-29 cells during the exponential growth phase were followed by pulse-chase experiments. After a $10 \mathrm{~min}$ pulse labelling with $\mathrm{D}-\left[2-{ }^{3} \mathrm{H}\right]-$ mannose, the cells were incubated in the presence of $5 \mathrm{mmol} / \mathrm{l}$ of non-radioactive mannose for 0-24 h; $2 \mathrm{mmol} / \mathrm{l}$ of non-radioactive fucose was also added to the culture medium in order to eliminate all interconversion of tritiated mannose into tritiated fucose, which had been previously demonstrated (OgierDenis et al, 1989). At each time interval, we determined the radioactivity associated with the dolichol-linked oligosaccharides (fig $1 \mathrm{~A}$ and $1 \mathrm{~B}$ ), the glycopeptides bearing the high mannose chains (fig $1 \mathrm{C}$ and $1 \mathrm{D}$ ) and the glycopeptides containing complextype chains (fig $1 E$ and $1 F$ ). The ratio of the radioactivity associated with the complex chains to that of the high mannose chains was calculated for the 2 cell populations during both of the cell growth phases considered (fig $1 \mathrm{G}$ and $1 \mathrm{H}$ ). The biosynthesis of lipid intermediates and their transfer onto the protein backbone were qualita- 
Table I. Distribution of the different glycoprotein fractions obtained after chromatography on a Bio-Gel P6 colum. HT-29 Glc ${ }^{-}$and HT-29 Glc cells, exponentially growing and confluent, were metabolically labeled with $\mathrm{D}-\left[2-{ }^{3} \mathrm{H}\right]-$ mannose for $24 \mathrm{~h}$. The glycopeptides obtained after Pronase digestion were separated by chromatography on a Bio-Gel P6 column. a : similar results were obtained previously for confluent cells (Ogier-Denis et al, 1988). Exp: exponential growth phase: Conf: confluent cells.

\begin{tabular}{lrrrr}
\hline \multirow{2}{*}{ Fractions } & \multicolumn{2}{c}{$H T-29 \mathrm{GlC}^{-}$} & \multicolumn{2}{c}{$H T-29 \mathrm{Glc}^{+}$} \\
\cline { 2 - 5 } & Exp & Conf ${ }^{\mathrm{a}}$ & Exp & Conf \\
\hline & & & & \\
Fraction I & 18 & 25 & 14 & 14 \\
Fraction II & 24 & 17 & 20 & 9 \\
Fraction III & 11 & 20 & 6 & 14 \\
Fraction IV & 47 & 38 & 60 & 63 \\
\hline
\end{tabular}

tively similar in the 2 cell populations during the exponential growth phase (fig $1 \mathrm{~A}$ and 1D). However, HT-29 Glc- cells undergo classic maturation of the high mannose chains into complex chains, whereas HT$29 \mathrm{Glc}^{+}$cells express only a very weak proportion of complex chains (fig $1 E$ and $(F)$. This deficiency in the mechanism of high mannose side chain maturation was confirmed by analysing the ratio of the radioactivity incorporated into the complex and the high mannose chains (fig $1 G$ and $1 \mathrm{H})$. The nature of the high mannose chains obtained following metabolic labelling (D-[2-3H]-mannose for $24 \mathrm{~h}$ ), was determined by HPLC after treatment with endo $H$. The results clearly demonstrate that the undifferentiated HT-29 Glc cells amass a high proportion of $\mathrm{Man}_{9-8^{-}}$ $\mathrm{GlcNAc}_{2}-$ Asn species, regardless of the growth phase studied (Ogier-Denis et al, 1989).

\section{DISCUSSION}

The results presented herein demonstrate that the $\mathrm{N}$-glycosylation process is independent of the growth phase in HT-29 cells, but depends greatly upon the capaci- ty or incapacity of the cells to differentiate after reaching confluence. In HT-29 Glccells, oligosaccharide transfer follows the classical pathway from dolichol to the polypeptide backbone, independently of the growth phase. The high mannose chains formed are thus quantitatively transformed into complex-type chains, as has been demonstrated for many eukaryote cells (Kornfeld and Kornfeld, 1985). In contrast, HT-29 Glc $^{+}$cells accumulate, in spite of their ability to engage in a classical mechanism for the biosynthesis of lipid intermediates, a very high proportion of high mannose chains. In addition, the maturation of the latter into complex-type chains is severely altered, regardless of the growth phase considered. The modifications of the $\mathrm{N}$-glycosylation process are thus present very early in HT-29 Glc cells. One of the most striking differences between the HT29 system and other cell models described by other authors is that the $\mathrm{N}$-glycan metabolism is independent of cell density and growth, but is directly linked to the differentiation program of HT-29 Glc- cells. In HT-29 Glc $^{+}$cells, the deficient metabolic step involves the conversion of high mannose chains, Man $_{9-8}-$ GlcNAc$_{2}-$ Asn into $\operatorname{Man}_{7-6-5}-$ GlcNAC $_{2}-$ Asn. The fact that this transformation is altered in undifferentiated 

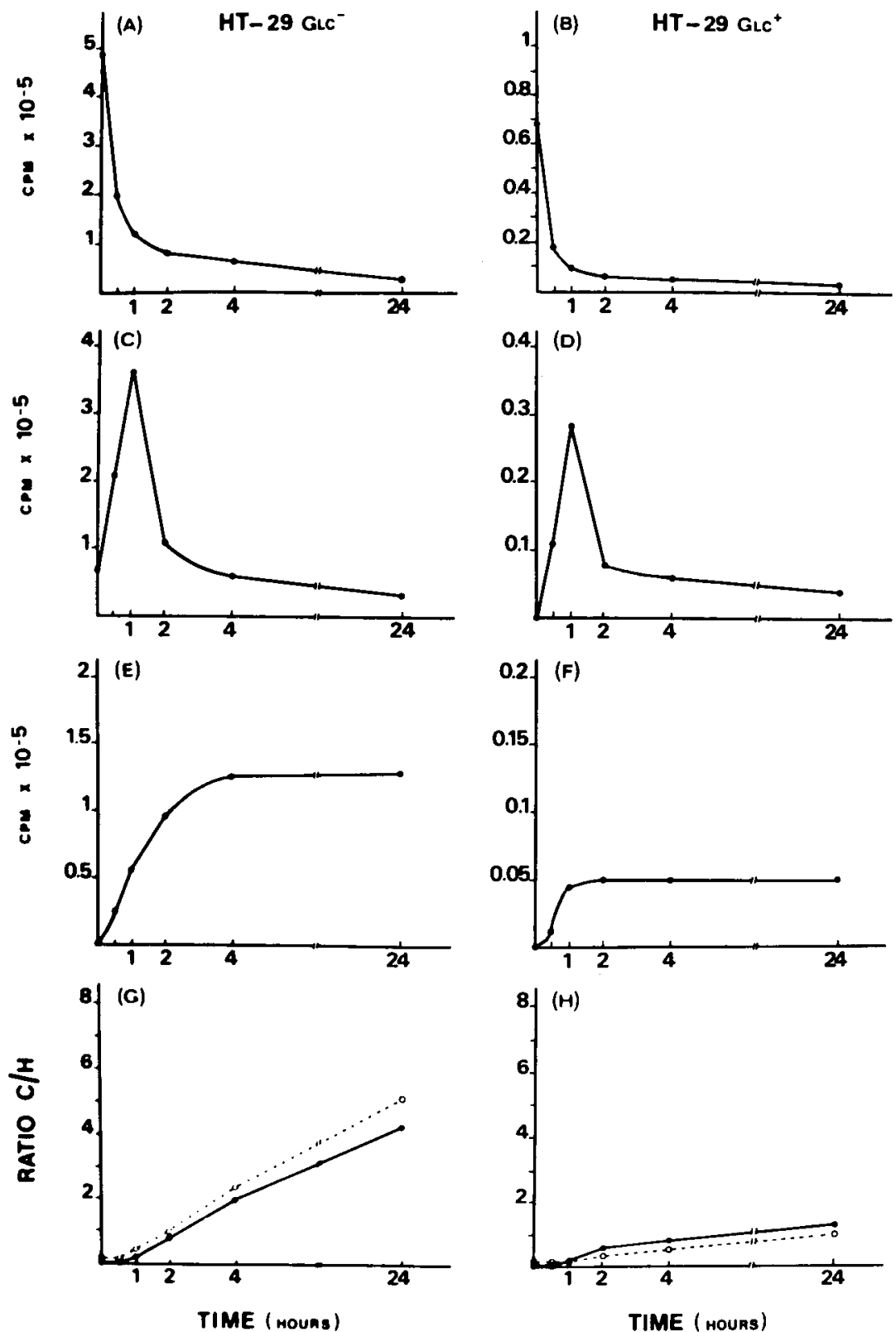

Fig 1. Fate of tritiated mannose incorporated in the different cell populations during a pulse-chase experiment. Growing HT29 Glc- (left panel) and HT-29 Glc (right panel) cells were pulsed for 10 min with $400 \mu \mathrm{Ci} / \mathrm{ml}$ of $\mathrm{D}-\left[2-{ }^{3} \mathrm{H}\right]-$ mannose, as described in the Materials and Methods section. The chase was performed for $0.5,1,2,4$ and $24 \mathrm{~h}$ in the presence of $5 \mathrm{mmol} / /$ unlabelled mannose and 2 $\mathrm{mmol} / \mathrm{l}$ unlabelled fucose. At each time, the lipid-linked oligosaccharides were extracted and the radioactivity of this lipid fraction determined (first row, A-B). The glycopeptides obtained after Pronase digestion were fractionated on a Bio-Gel P6 column. The radioactivity recovered in the high mannose fraction (fraction IV endo $\mathrm{H}$-sensitive) was plotted in the 2 nd row (C-D). The radioactivity recovered in the complex fractions was plotted in the 3rd row (E-F). In the last row, we report the ratio of the radioactivity in complex/high mannose glycopeptides (ratio $\mathrm{C} / \mathrm{H}$ ) in exponential cells, and the dotted lines correspond to the results obtained previously with corresponding confluent cells (Ogier-Denis et al, 1988). 
HT-29 Glc ${ }^{+}$cells, regardless of the growth phase considered, raises the question as to the regulation of this enzymatic reaction. Future studies will reveal whether the alterations observed in the $\mathrm{N}$-glycosylation process result from a regulation of the genetic control or an early regulation of $\mathrm{N}$ glycan metabolism. Although the 2 cell populations are morphologically and enzymatically indistinguishable during the exponential growth phase, it is now possible to differentiate between them using an early biochemical marker, ie, N-glycosylation of proteins. Thus, the $\mathrm{N}$-glycosylation mechanism seems to be a sensitive and early indicator of the capacity of HT-29 cells to enter into the complex pathway of cellular differentiation.

\section{ACKNOWLEDGMENTS}

This work was supported by Institut National de la Santé et de la Recherche Médicale (INSERM), Association pour la Recherche sur le Cancer (ARC), Groupement des Entreprises Françaises de Lutte contre le Cancer (GEFLUC) and Fondation pour la Recherche Médicale (FRM).

\section{REFERENCES}

Codogno P, Botti J, Font J, Aubery M (1985) Modification of the $\mathrm{N}$-linked oligosaccharides in cell surface glycoproteins during chick em- bryo development. A using lectin affinity and a high resolution chromatography study. Eur J Biochem 149, 453-460

Fogh J, Trempe G (1975) New human tumor cell lines. In: Human Tumor Cells in vitro (Fogh J, ed), Plenum Published Corp, New York

Kornfeld R, Kornfeld S (1985) Assembly of asparagine-linked oligosaccharides. Annu Rev Biochem 54, 631-664

Ogier-Denis E, Codogno P, Chantret I, Trugnan $G$ (1988) The processing of asparaginelinked oligosaccharides in HT-29 cells is a function of their state of enterocytic differentiation: an accumulation of $\mathrm{Man}_{9-8}-\mathrm{GlcNAC}_{2}-$ Asn species in indicative of an impairment $\mathrm{N}$ glycan trimming in undifferentiated cells. $J$ Biol Chem 263, 6031-6037

Ogier-Denis E, Bauvy C, Aubery M, Codogno $P$, Sapin C, Rousset M, Zweibaum A, Trugnan $G$ (1989) The processing of asparaginelinked oligosaccharides is an early biochemical marker of the enterocytic differentiation of HT-29 cells. J Cell Biochem 41, 13-23

Roméro PA, Herscovics A (1986) Transfer of non glucosylated oligosaccharides from lipid to protein in a mammalian cell. $J$ Biol Chem 261, 15936-15940

Tarentino AL, Maley $F$ (1974) Purification and properties of a endo- $\beta$ - $\mathrm{N}$-acetyl-glucosaminidase from Streptomyces griseus. $J$ Biol Chem 249, 811-817

Zweibaum A, Pinto M, Chevalier G, Dussaulx E, Triadou N, Lacroix B, Haffen K, Brun JL, Rousset M (1985) Enterocytic differentiation of subpopulation of the human colon tumor cell line HT-29 selected for growth in sugarfree medium and its inhibition by glucose. $J$ Cell Physiol 122, 21-29 